\title{
Statement by Burhan Gafoor
}

\author{
Chair of the Sixth Committee of the General Assembly at Its Seventy- \\ Second Session
}

We are meeting here on this very special occasion to pay tribute to the International Law Commission. It is not often that an international body celebrates seventy years of continued existence. The International Law Commission has not only existed for 70 years, it has made a significant contribution to progressive development and codification of international law, as well as to the work of the United Nations.

I am honoured to speak today in my capacity as Chair of the Sixth Committee of the seventy-second session of the General Assembly. The commemoration of the International Law Commission is also in many ways a commemoration of the work of the Sixth Committee. The International Law Commission and Sixth Committee are partners in the promotion of international law. We have worked very closely, as envisaged in General Assembly resolutions as well as the statute of the Commission. This working relationship and partnership is on full display each year at what has come to be known as "International Law Week", during which the Sixth Committee debates and considers the annual report of the International Law Commission to the General Assembly. This is an important avenue for members of the Sixth Committee to provide guidance and substantive inputs to the Commission, which in turn helps to develop and progress the work of the Commission. Equally important are the informal interactions that occur between the Committee and the Commission during this time of the General Assembly. Such interactions help to foster a deeper understanding between the two bodies that is so crucial for this partnership to work. In this regard, I am particularly pleased with the many opportunities for interaction over the past weeks, as evidenced by the numerous side events held at the sidelines of the Commission's meetings.

It is worth recalling that the establishment of the International Law Commission came from a recommendation of the Sixth Committee at its second session in 1947, with elections of members of the Commission taking place in 1948. Indeed, the Commission helps the General Assembly to discharge its Charter responsibility to initiate studies and make recommendations to encourage the progressive development of international law and its codification.

The Commission's annual meetings since 1949, and its work over the years, have led to the adoption of many substantive texts. The areas covered have ranged from the law of the sea to contemporary challenges like protection of 
the atmosphere and the responsibility of international organizations, as well as the immunity of State officials from foreign criminal jurisdiction. The wide areas of coverage, together with the large number of instruments eventually adopted, is impressive. Over the years, 17 multilateral conventions have been concluded under the auspices of the United Nations based on drafts prepared by the Commission. Equally impressive is the intellectual rigour and scholarship that have informed these outcomes, thanks to the contribution and hard work of members of the Commission.

There is no doubt that the International Law Commission has made an indispensable contribution to the progressive development and codification of international law. After 70 years, the role of the Commission remains as important as ever, especially at a time when multilateralism is being challenged. At this time, it is important for members of the United Nations to defend the multilateral rules-based system and the principles of international law. At the same time, the United Nations has a responsibility to continue to develop new norms and rules and codify State practice in the field of international law. The work of the International Law Commission has therefore become critical as a vehicle to reinforce the multilateral rules-based system. The strength of the Commission is that it is an independent body of experts who represent the principal legal systems of the world. Therefore, the work of the Commission can help to build understanding, bridge differences and lay the groundwork for political decisions to be made by Member States in the General Assembly.

As we look beyond, there is one particular area that deserves mention on an occasion like this. In the last seven decades, only seven women jurists have served on the International Law Commission, namely Paula Escarameia, Hanqin Xue, Concepción Escobar Hernández, Marie Jacobsson, Marja Lehto, Patricia Galvão Teles, and Nilüfer Oral. At this rate, it will take more than 100 years to achieve gender parity. This is certainly not acceptable and clearly an area for improvement, for both the General Assembly and the Commission. All members of the United Nations have a responsibility to nominate women candidates to the Commission. It is my hope that we can all work together to bring gender parity to the Commission and hopefully we can achieve this when we celebrate the 8oth anniversary of the Commission.

Let me conclude by saying that the relationship between the Sixth Committee and the International Law Commission is a special and long-standing one. On the one hand, the Commission looks at issues from an independent, technical and academic perspective. On the other hand, the Sixth Committee attempts to build political consensus on legal issues, so that legal instruments can be adopted by the United Nations. It is an organic and symbiotic relationship that is based on a common objective, which is to support the progressive 
development and codification of international law and to strengthen the multilateral rules-based system. On behalf of all members of the Sixth Committee, I can say with confidence that we are proud of the work done by the International Law Commission in the last 70 years. I take this opportunity to acknowledge the work done by each member of the Commission and the Chair of the Commission. You have our support and our appreciation. The Committee looks forward to continuing its engagement and partnership with the Commission in the service of international law and the United Nations. 